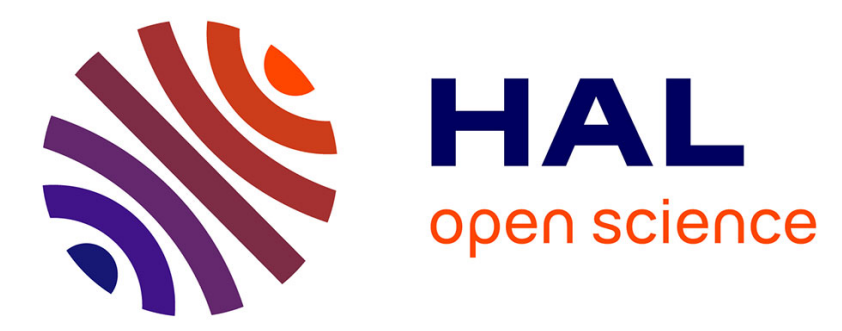

\title{
Estimation of the atmospheric surface momentum and heat fluxes using a high resolution acoustic radar
}

C. Helmis, J. Kalogiros, K. Papadopoulos, A. Soilemes, D. Asimakopoulos

\section{To cite this version:}

C. Helmis, J. Kalogiros, K. Papadopoulos, A. Soilemes, D. Asimakopoulos. Estimation of the atmospheric surface momentum and heat fluxes using a high resolution acoustic radar. Journal de Physique IV Proceedings, 1994, 04 (C5), pp.C5-287-C5-290. 10.1051/jp4:1994559 . jpa-00253054

\section{HAL Id: jpa-00253054 https://hal.science/jpa-00253054}

Submitted on 1 Jan 1994

HAL is a multi-disciplinary open access archive for the deposit and dissemination of scientific research documents, whether they are published or not. The documents may come from teaching and research institutions in France or abroad, or from public or private research centers.
L'archive ouverte pluridisciplinaire $\mathbf{H A L}$, est destinée au dépôt et à la diffusion de documents scientifiques de niveau recherche, publiés ou non, émanant des établissements d'enseignement et de recherche français ou étrangers, des laboratoires publics ou privés. 


\title{
Estimation of the atmospheric surface momentum and heat fluxes using a high resolution acoustic radar
}

\author{
C.G. HELMIS, J.A. KALOGIROS, K.H. PAPADOPOULOS, A.T. SOILEMES and \\ D.N. ASIMAKOPOULOS
}

Department of Applied Physics, University of Athens, 33 Ippokratus Str., 10680 Athens, Greece

\begin{abstract}
The surface heat flux $\left(Q_{O}\right)$ and the friction velocity $\left(u_{\star}\right)$ are important parameters of the Atmospheric Boundary Layer (ABL). Vertical velocity variance $\left(\sigma_{W}{ }^{2}\right)$ profiles have been used to estimate the parameters $Q_{0}$ and $u_{*}$ from Acoustic Sounder (AS) data according to the similarity theory. A comparison was made using data from a $12 \mathrm{~m}$ high mast equipped with humidity, and fast responding wind and temperature sensors and a high resolution monostatic AS. The comparison confirms the ability of the $\sigma_{w}{ }^{2}$ profile method to provide, even in a noisy environment (inhabitant area), estimates of these parameters with reasonable accuracy and on a continuous basis. The requirements for the method to be applied is that convective conditions or a minimum mechanical mixing exist and the level of acoustic noise is not too high.
\end{abstract}

\section{INTRODUCTION}

AS systems have been widely used to monitor the $A B L$ the last twenty years $[1,2]$. The facsimile records of a monostatic $A S$ depict the thermal structure of the $A B L$ while three monostatic AS can give with Doppler measurements the components of the wind velocity vector [2]. The AS can give continuous records of data with the advantage that they are less sensitive to local conditions due to volume averaging and they extent to heights much higher than the limits of most meteorological towers. Recent studies concerning the accuracy of second moments of the components of the wind measured with AS showed that only the vertical velocity variance $\left(\sigma_{W}\right)$ measurements are accurate enough for useful purposes [3]. Using high resolution AS the accuracy of the measured $\sigma_{\mathrm{W}}{ }^{2}$ can be improved [4].

While the most of the studies using AS have been performed over land, a few of them that were conducted over the ocean proved that the acoustic wind profiler can be used also for reliable monitoring of the marine boundary layer [5]. In this work data from a study with the use of AS concerning the sea-breeze front on the coast line in an inhabitant area are presented. Using the $\sigma_{W}{ }^{2}$ profile method described in the next section the ability of the AS systems to accurately estimate the surface heat flux $\left(Q_{O}\right)$ and the friction velocity $\left(u_{*}\right)$ is demonstrated. 


\section{THE $\sigma_{w}^{2}$ PROFILE METHOD}

Many workers have been used the $\sigma_{w}^{2}$ measurements by an AS and profile methods based on similarity theory to evaluate the heat flux and the first inversion height under convective atmospheric conditions $[6,7]$. The profile of $\sigma_{W}$ in the surface layer is well-known $[8]$ :

$$
\sigma_{W} / u_{*}= \begin{cases}1.25(1-3.43 z / L)^{1 / 3} & , L<0 \text { (unstable conditions) } \\ 1.25 & , L>0 \text { (stable conditions) }\end{cases}
$$

where $z$ the height above surface, $L=-u_{*} 3 /\left(\mathrm{kgQ}_{0} / \Theta\right)$ the Monin-Obukhov length, $k=0.35$ the Von Karman constant, $g$ the acceleration of gravity, $\Theta$ the mean potential temperature, $Q_{0}=\left\langle w^{\prime} \Theta^{\prime}>_{0}\right.$ and $u_{*}^{2}=<-u^{\prime} w^{\prime}>_{0}$. In the mixed layer $Q_{0}$ is replaced by the local heat flux $Q$, which under convective conditions is nearly a linear function of height [8]:

$Q(z)=Q_{0}\left[1-(1+a) z / z_{i}\right]$

where $z_{i}$ is the inversion height and $a=-Q\left(z_{j}\right) / Q_{0}$ is the entrainment coefficient (about 0.22 under developed convection). It should be noted that generally $\Theta$ should be replaced by the virtual potential temperature in order to incorporate in the buoyancy the contribution of moisture flux which is important over sea [8]. Because of lack of moisture flux measurements such a correction was not applied to our results.

The substitution of (2) in (1) generally leads to a second degree polynomial of $z$ for $\sigma_{w}{ }^{3}$. The degree and the parameters of the polynomial are evaluated with a least squared error fit and a t-test on the correlation coefficient. First, the values of vertical velocity measured by the AS are corrected using the noise level as a criterion and a linear prediction scheme involving the neighbour gates at the three prior shots. The upper noisy gates with a correction more than $20 \%$ are rejected and do not take part in the polynomial fit. Also, the polynomial fit should have parameters of the right sign to be accepted.

\section{EXPERIMENTAL. RESULTS}

During the summer of 1992 an experiment concerning the study of the sea-breeze front was carried out in a inhabitant area close to the coast line of Saronic Gulf. A high-resolution AS was operated at a frequency of $4.3 \mathrm{kHz}$, with pulse repetition rate of $5 \mathrm{sec}$ and a range of $400 \mathrm{~m}$. The acoustic antenna is comprised by an array of $5 \times 5$ piezoelectric tweeters (Motorola) with the corner elements removed. The vertical component of the wind and the thermal structure of the lower ABL were continuously recorded for a time period of two months. A 12 $m$ high mast equipped with UVW propeller and cup anemometers, wind vane, humidity and fast responding temperature sensors, was erected close to the AS. The results of a typical experimental day in 45 minutes runs are presented in the next paragraphs.

During the 4th of July 1992 a weak north flow was present in the Athens basin and the formation of the sea-breeze circulation was delayed. The sea-breeze front crossed the shoreline after 1115 LST as it can be seen by the change in thermal structure from organized thermal plumes to a low activity in Figure 1. At the same time the sea-breeze signature is evident in Figure 2 with a drop of temperature $(T)$, an increase of relative humidity $(\mathrm{RH})$ and wind speed $(U)$ and a change of wind direction to 200 degrees (coming from the sea). The seabreeze lasted until late evening. 


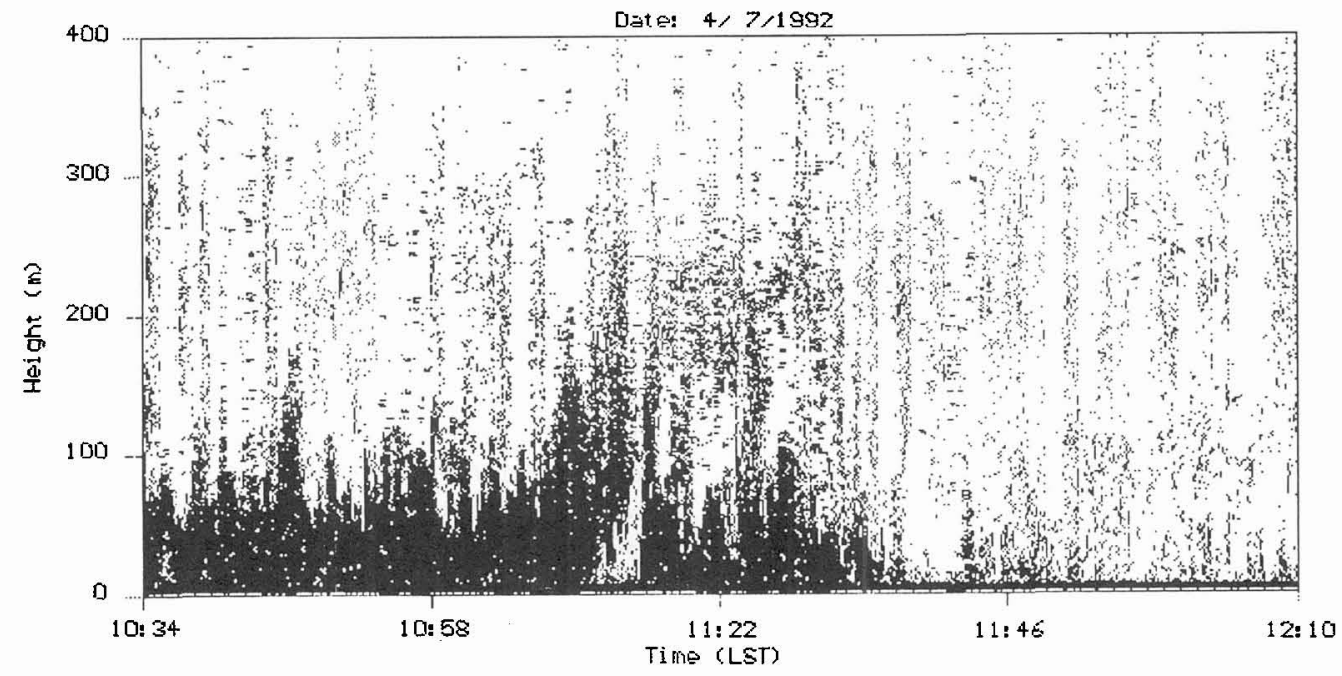

Figure 1. Facsimile record of the AS on 4 July 1992.

In Figure $3, Q_{0}$ and $u_{*}$ computed from the AS data using the $\sigma_{w}$ profile method and the eddy correlation method are compared. The AS results follow the eddy correlation method ones even though the environment was quite noisy (many estimates for $Q_{0}$ are missing)

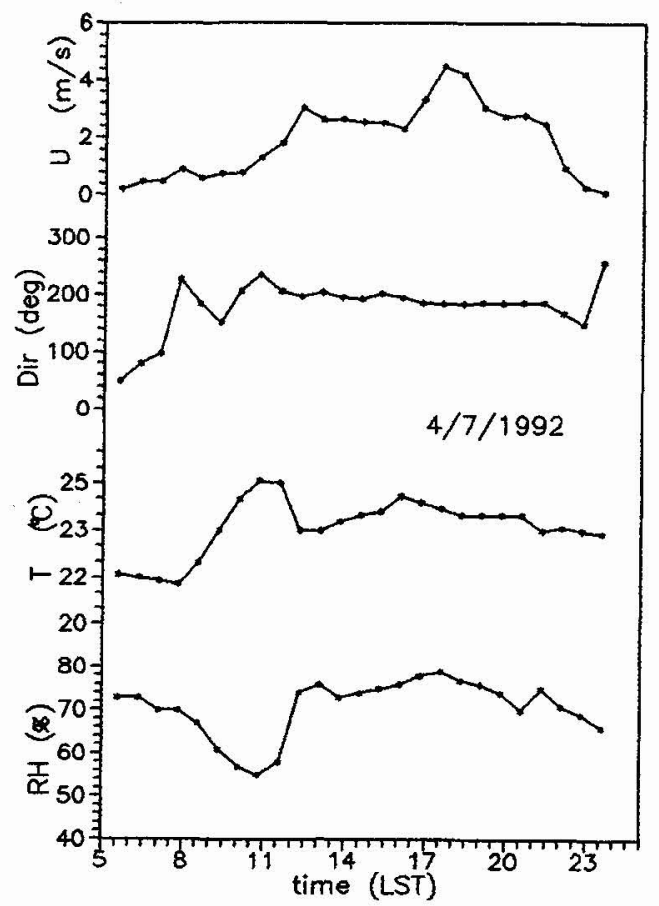

Figure 2. Time series of wind speed, and direction, temperature and relative humidity measured at $10 \mathrm{~m}$ height on 4 July 1992.

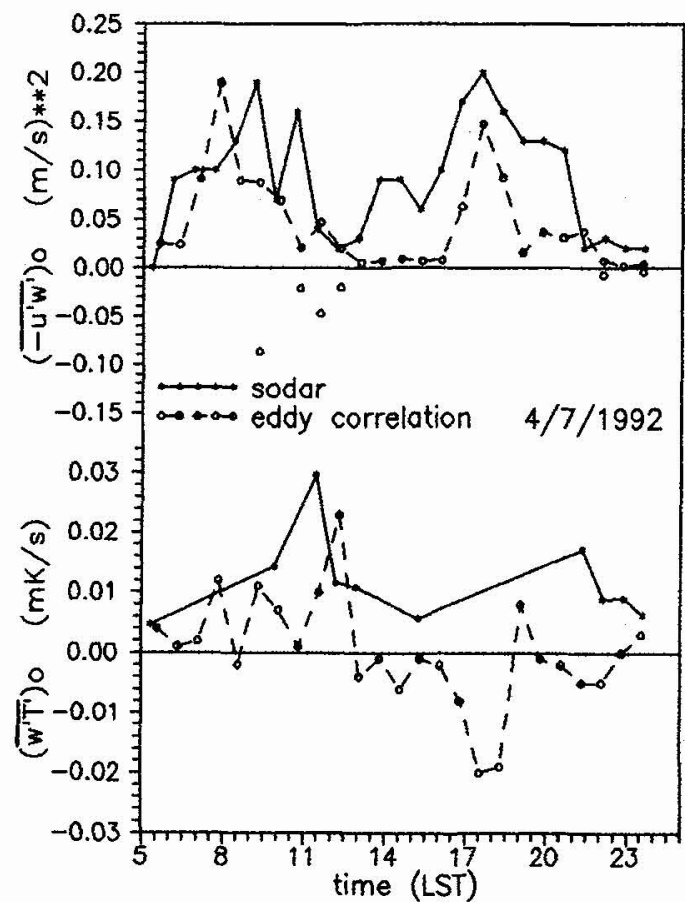

Figure 3. Time series of momentum and heat flux estimates using the sodar and the eddy correlation methods on 4 July 1992. 


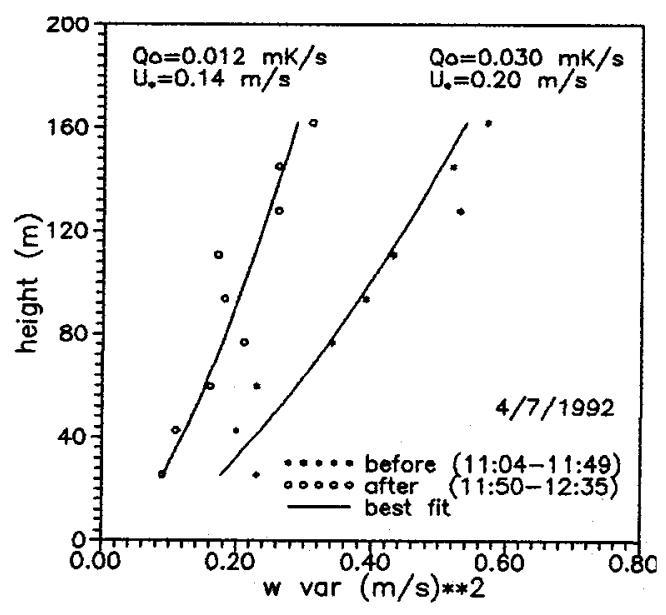

Figure 4. Vertical velocity variance profiles on 14 July 1992, before and after the passage of sea-breeze front. and there was no correction due to moisture flux as it was explained in section 2. Also, we must note that the profile method cannot give the sign of the momentum flux and only positive heat fluxes (unstable conditions) can be computed. The decrease of the momentum and the heat flux with the passage of seabreeze front after 1115 LST is evident in the results of both methods. The peak in $u_{*}$ after 1700 LST is coupled with an increase of wind speed shown in Figure 2. Figure 4 shows the change of the $\sigma_{w}{ }^{2}$ profile for two consecutive runs at the passage of the sea-breeze front. The change of the slope of the profile corresponds to a drop of surface heat flux. The same kind of results were provided under different meteorological conditions but are not presented due to limited space.

\section{CONCLUDING REMARKS}

A method has been developed to provide continuous and reasonably accurate estimates of $u_{*}$ and $Q_{0}$ using average profiles of the vertical component of the wind $\sigma_{W}{ }^{2}$ measured by a monostatic AS, provided that thermal or low mechanical activity exists. The method uses wellknown similarity relations for the $\sigma_{W}$ profile in the $A B L$ and applies a polynomial fit to the measured profile. Special care is taken to reject possible outlier points at the upper altitudes of the profile due to environmental noise.

Acknowledgements. We would like to thank the Ministry of the Environment, Physical Planning and Public Works and UNEP (MED-POL programme) for financial support.

\section{REFERENCES}

[1] Asimakopoulos D.N., Helmis C.G. and Deligiorgi D.G., "Climatological evaluation of Sodar recordings over complex terrain", 6th Symposium on Acoustic Remote Sensing and Associated Techniques of the Atmosphere and Oceans, Athens 26-29 May 1992, pp. 11-22.

[2] Neff, W.D., and Coulter R.L., Probing the Atmospheric Boundary Layer, (D. Lenschow, Amer. Met. Soc., Boston, 1986) pp. 201-239.

[3] Gaynor J.E., "Quantifying errors in sodar wind variance measurements", 6th Symposium on Acoustic Remote Sensing and Associated Techniques of the Atmosphere and Oceans, Athens 26-29 May, pp. 47-52.

[4] Helmis C.G., Asimakopoulos D.N., and Cole R.S., IEEE-Geoscience and Remote Sensing GE-23 (1985) 164-170.

[5] Bradley S. and George K., "Low-level Acoustic wind profiling from a small sea-going vessel", 6th Symposium on Acoustic Remote Sensing and Associated Techniques of the Atmosphere and Oceans, Athens 26-29 May 1992, pp. 249-254.

[6] Weill A., Klapisz C., Strauss B., Baudin F., Jaupart C., Van Grunderbeeck P. and Goutorbe J.P., J. Appl. Meteor. 19 (1986) 199-205.

[7] Keder J., Foken Th., Gerstmann W. and Schindler V., Bound. Layer. Meteor. 46 (1989) 195-204.

[8] Stull R.B., An introduction to Boundary Layer Meteorology (Kluwer Academic Publishers, 1989), $666 \mathrm{pp}$. 